\title{
Co dalej z projektem nowej ordynacji podatkowej?
}

W artykule przedstawiono argumenty za uchwaleniem nowej ordynacji podatkowej według projektu przygotowanego przez Komisję Kodyfikacyjną Ogólnego Prawa Podatkowego. Do obowiązującej ordynacji - na skutek kolejnych nowelizacji - wprowadzano nowe instrumenty służące uszczelnianiu systemu podatkowego. Mankamentem ustawy jest brak regulacji charakterystycznych dla nowoczesnych aktów tego typu. Ordynacja obowiązuje już ponad 20 lat i z powodów obiektywnych zdezaktualizowała się część jej unormowań. Zasady techniki legislacyjnej nie pozwalają w wielu przypadkach na ich modyfikację, można to zrobić jedynie w nowej ustawie. W ocenie autora parlament powinien opracować nową ordynację podatkową, opierając się na wspomnianym projekcie.

Słowa kluczowe: projekt ustawy, ordynacja podatkowa

What next with the draft of the new Tax Ordinance Act?: The article presents arguments for adopting a new Tax Ordinance Act according to a draft prepared by the General Tax Law Codification Commission. The current regulations - as a result of subsequent amendments - introduced new instruments aimed at sealing the tax system. The disadvantage of the tax ordinance is the lack of regulations specific to modern acts of this type. The ordinance has been in force for over 20 years and due to objective reasons some of its norms have become outdated. The rules of legislative technique do not allow for their modification in many cases. This can only be done in a new statute. In the author's opinion, the parliament should develop a new tax ordinance act based on the aforementioned draft.

Keywords: bill, tax ordinance act

Profesor doktor hab. nauk prawnych, Wydział Prawa Uniwersytetu w Białymstoku, przewodniczący Komisji Kodyfikacyjnej Ogólnego Prawa Podatkowego • leonard.etel@wp.pl • https://orcid.org/0000-0001-8065-2276

\section{Wstęp}

Prace nad projektem nowej ordynacji podatkowej (dalej: NOP) rozpoczęły się w październiku 2014 r. W celu przygotowania projektu została powołana Komisja Kodyfikacyjna Ogólnego Prawa Podatkowego (dalej: KKOPP lub Komisja). W skład Komisji weszło: pięcioro przedstawicieli nauki prawa podatkowego, troje sędziów sądów administracyjnych, troje przedstawicieli organów podatkowych, troje przedstawicieli firm doradztwa podatkowego i przedstawiciel Prezydenta RP. Zgodnie z $\$ 8$ rozporządzenia powołującego $\mathrm{KKOPP}^{1}$ do jej zadań

1 Rozporządzenie Rady Ministrów z dnia 21 października 2014 r. w sprawie utworzenia, organizacji i trybu działania Komisji Kodyfikacyjnej Ogólnego Prawa Podatkowego, Dz.U. poz. 1471, ze zm. 
należało: opracowanie, nie później niż w terminie 4 miesięcy od dnia pierwszego posiedzenia Komisji, kierunkowych założeń kompleksowej regulacji rangi ustawowej dotyczącej ogólnego prawa podatkowego oraz opracowanie, nie później niż w terminie 2 lat od dnia przyjęcia kierunkowych założeń, projektu ustawy zawierającego kompleksowe regulacje dotyczące ogólnego prawa podatkowego wraz z przepisami wykonawczymi. Zadania te KKOPP zrealizowała w terminie, przygotowując kierunkowe założenia nowej ordynacji podatkowej i na ich podstawie projekt ustawy - Ordynacja podatkowa, projekt ustawy - Przepisy wprowadzające ustawę - Ordynacja podatkowa oraz projekty przepisów wykonawczych. Projekty te trafiły do Ministra Finansów w październiku 2017 r. i zostały przekazane do konsultacji, a następnie, po uwzględnieniu zgłoszonych uwag, zostały skierowane do Sejmu w czerwcu 2019 r. (druk sejmowy nr 3517/VIII kad.). Pierwsze czytanie miało miejsce 3 lipca 2019 r. Następnie projektami zajęła się Komisja Finansów Publicznych, powołując w tym celu podkomisję, której posiedzenie odbyło się w lipcu 2019 r. Koniec kadencji Sejmu spowodował, że prace nad projektem - zgodnie z zasadą dyskontynuacji prac parlamentarnych zostały przerwane. Celem artykułu jest wskazanie argumentów przemawiających za koniecznością ich dalszego prowadzenia, wynikającą z potrzeby uchwalenia nowej ordynacji podatkowej.

\section{Dlaczego ordynacja podatkowa zmienia się kilkanaście razy w roku?}

Ordynacja podatkowa uchwalona 29 sierpnia 1997 r. obowiązuje już ponad 20 lat (dalej: ordynacja podatkowa lub o.p.). Ponieważ był to okres dynamicznego rozwoju prawa podatkowego w Polsce, podlegała ona w tym czasie częstym nowelizacjom. Akt ten był - w różnym zakresie - zmieniany ponad 160 razy. To negatywne zjawisko utrzymuje się, a w ostatnich latach nawet nasila. W $2018 \mathrm{r}$. ordynację zmieniono 17 razy, a do 1 października 2019 r. - 16. Już po ukazaniu się ostatniego tekstu jednolitego (kwiecień 2019 r.) $)^{2}$ ustawę nowelizowano 13 razy, co wskazuje, że w najbliższym czasie powinien być ogłoszony kolejny tekst jednolity ${ }^{3}$. Do tej pory ogłoszono 6 tekstów jednolitych, $\mathrm{z}$ tego $3 \mathrm{w}$ latach 2017-20194. Nie wymaga uzasadnienia twierdzenie, że akt o charakterze kodeksowym nie powinien mieć co roku tekstu jednolitego.

2 Obwieszczenie Marszałka Sejmu Rzeczypospolitej Polskiej z 25 kwietnia 2019 r. w sprawie ogłoszenia jednolitego tekstu ustawy - Ordynacja podatkowa, Dz.U. poz. 900.

3 Zmiany tekstu jednolitego ustawy zostały ogłoszone w Dz.U. 2019, poz. 924, 1018, 1495, 1520, 1553, 1556, 1649, 1655, 1667, 1751, 1818, 1978 i 2020.

4 Teksty jednolite były ogłaszane w roku 2005, 2012, 2015, 2017, 2018 i 2019. 
Jaka jest przyczyna tak częstych nowelizacji? Analiza głównych zmian wprowadzonych do tego aktu w ostatnich latach pozwala stwierdzić, że dotyczą one szeroko rozumianego procesu uszczelniania systemu podatkowego. Ich celem jest ograniczenie możliwości ucieczki od płacenia podatków. Większość instrumentów prawnych mających temu służyć została wprowadzona do ordynacji w wyniku implementacji dyrektyw unijnych, realizujących m.in. opracowany przez OECD „Plan działan BEPS (Base Erosion and Profit Shifting)”5. W wyniku tego procesu w ordynacji dokonano bardzo obszernych zmian, wprowadzając przepisy dotyczące: informacji o schematach podatkowych (dział III rozdział 11a), systemu teleinformatycznego izby rozliczeniowej (dział IIIB - Przeciwdziałanie wykorzystaniu sektora finansowego do wyłudzeń skarbowych), przebudowano przepisy regulujące klauzulę przeciwko unikaniu opodatkowania, normując m.in. cofnięcie skutków unikania opodatkowania (dział IIIa rozdział 5) oraz dodatkowe zobowiązanie podatkowe (dział III rozdział 6a). Na tym nie koniec. $\mathrm{W}$ październiku 2019 r. dokonano zmian $\mathrm{w}$ zakresie porozumień $\mathrm{w}$ sprawach ustalania cen transferowych ${ }^{6}$. Konieczność zwalczania zjawisk uchylania się od opodatkowania i unikania opodatkowania skutkuje ciągłą potrzebą kreowania nowych instrumentów prawnych, które po pewnym czasie muszą być modyfikowane albo zastąpione innymi, dostosowanymi do zmieniających się metod działań nieuczciwych podatników.

Jedynym sposobem zminimalizowania negatywnego wpływu tego procesu na zachowanie niezbędnej stabilności ordynacji podatkowej jest wprowadzenie tych zmian w formie odrębnych ustaw (albo ustawy). Dobrym przykładem jest ustawa z 9 marca 2017 r. o wymianie informacji podatkowych pomiędzy innymi państwami (Dz.U. poz. 648, ze zm.). Regulacje dotyczące wymiany tych informacji zostały przeniesione $\mathrm{z}$ ordynacji do tej ustawy, co było postulowane przez $\mathrm{KKOPP}^{7}$. Ta bardzo obszerna ustawa (111 artykułów) była już 3 razy zmieniona i, jak należy sądzić $\mathrm{z}$ uwagi na przedmiot regulacji, tych zmian będzie więcej. Nie bez znaczenia jest również to, że uregulowanie tej materii w nowej ustawie wpłynęło pozytywnie - o czym niżej - na poprawę struktury i objętości ordynacji podatkowej.

$\mathrm{W}$ dobrym kierunku poszły również zmiany $\mathrm{w}$ regulacjach dotyczących porozumień w sprawach ustalania cen transferowych. Zagadnienia te zostały usunięte $\mathrm{z}$ ordynacji podatkowej (dział IIa) i unormowane w uchwalonej już nowej ustawie o rozstrzyganiu sporów dotyczących podwójnego opodatkowania oraz

5 Action Plan on Base Erosion and Profit Shifting, https://www.oecd.org/ctp/BEPSActionPlan.pdf.

6 Ustawa z 16 października 2019 r. o rozstrzyganiu sporów dotyczących podwójnego opodatkowania oraz zawieraniu uprzednich porozumień cenowych, Dz.U. poz. 2200.

7 Zob. L. Etel i in., Ordynacja podatkowa. Kierunkowe założenia nowej regulacji, Białystok 2015, s. 19. 
zawieraniu uprzednich porozumień cenowych (Dz.U 2019, poz. 2200). Ceny transferowe są także obszarem bardzo niestabilnym, a regulacja ich dotycząca została dosyć przypadkowo umieszczona w strukturze ordynacji podatkowej (art. 20a-20r o.p.).

W trakcie prac KKOPP wskazywano na możliwość uregulowania instrumentów uszczelniających system podatkowy w jednej ustawie. Byłaby to ustawa całościowo ujmująca to zagadnienie, a przez to łatwiejsza w odbiorze, zwłaszcza przez podatników. Normowanie tych instrumentów w różnych ustawach, przy tak dużej ich różnorodności, skutkuje trudnościami w zapoznaniu się z nimi przez adresatów prawa. Nie jest to jednak kwestia zasadnicza z uwagi na konieczność ochrony ordynacji przed ciągłymi zmianami. Chcąc, aby najważniejszy akt z zakresu prawa podatkowego (nazywany konstytucją podatkową) nie był zmieniany kilkanaście razy w roku, należy uregulować odrębnie instrumenty prawne wykorzystywane do walki z ucieczką od podatków. Postulat ten obejmuje także zawarte już w ordynacji przepisy regulujące klauzulę przeciwko unikaniu opodatkowania, raportowanie schematów podatkowych oraz system teleinformatyczny izby rozliczeniowej. Nie powinny one być przedmiotem regulacji zawartych w projekcie NOP, co postulowała KKOPP, opiniując wprowadzone zmiany. Są to niewątpliwie regulacje ogólnego prawa podatkowego, które jednak z uwagi na ich specyfikę i dynamikę zmian, muszą być uregulowane w odrębnych ustawach.

Ich wyprowadzenie poza ordynację poprawi także strukturę tego aktu oraz zmniejszy jego objętość.

\section{Brak w obowiązującej ordynacji nowoczesnych instytucji ogólnego prawa podatkowego}

W ordynacji nie ma nowoczesnych instytucji charakterystycznych dla współczesnego ogólnego prawa podatkowego ${ }^{8}$. Ustawa uchwalona pod koniec ubiegłego wieku nie mogła, z przyczyn obiektywnych, zawierać regulacji będących dzisiaj

8 W literaturze powszechnie wskazuje się na potrzebę uchwalenia nowej ordynacji zob. B. Brzeziński, Ordynacja podatkowa w świetle kryteriów oceny jakości aktów normatywnych [w:] Ordynacja podatkowa. Wokót nowelizacji, red. R. Dowgier, Bialystok 2009, s. 23 i n.; Konferencja „Zmiany w Ordynacji podatkowej. Poprawa jakości i uproszczenia”, Warszawa, 8 stycznia 2013 r., red. G. Gołębiowski, H. Dzwonkowski, Warszawa 2013, s. 7-11; C. Kosikowski, Ogólny kodeks daninowy zamiast ordynacji podatkowej, „Przegląd Podatkowy” 2014, nr 9, s. 11-17; R. Dowgier, O konieczności uwzględnienia $w$ ordynacji podatkowej specyfiki podatków samorządowych [w:] Ordynacja podatkowa. Stan obecny i kierunki zmian, red. R. Dowgier, Warszawa 2015, s. 63-64; R. Mastalski [w:] B. Adamiak, J. Borkowski, R. Mastalski, J. Zubrzycki, Ordynacja podatkowa. Komentarz, Wrocław 2014, s. 5. 
standardem w obowiązujących aktach tego typu'. Postępujące w ostatnim czasie zmiany w relacjach podatnik - fiskus wymuszają modyfikację „starzejącej się" ordynacji podatkowej. Jest to jedna z podstawowych przyczyn niestabilności tego aktu. Najnowszym przykładem jest wprowadzenie do ordynacji podatkowej umowy o współdziałanie ${ }^{10}$. Jest to nowoczesny instrument prawny umożliwiający organowi podatkowemu ułożenie wzajemnych stosunków z podatnikiem, na podstawie ustaleń wynikających z umowy (porozumień), obopólnie korzystnych i zachęcających do współpracy. Tej instytucji oczywiście nie mogło być w ordynacji uchwalonej w 1997 r. Obecnie funkcjonuje ona z powodzeniem w innych państwach jako program poprawnego rozliczania opartego na współpracy (cooperative compliance) ${ }^{11}$. Jej wprowadzenie do polskiego porządku prawnego należy ocenić pozytywnie - ale nie tylko tej instytucji brakuje w obowiązującej ustawie. Równie dobre rezultaty jak umowa o współdziałanie przynoszą stosowane $\mathrm{w}$ innych systemach tzw. niewładcze sposoby załatwiania sprawa podatkowych $^{12}$. Zaliczają się do nich m.in. umowy podatkowe i mediacje. One także powinny trafić do ordynacji w najbliższym czasie, co może wiązać się z kolejną nowelizacją jej treści. Nie jest to racjonalny tryb doskonalenia aktu prawnego tej rangi. Rozwiązaniem zasygnalizowanego problemu jest przygotowanie nowego aktu, w którym uwzględni się nowe instytucje, niezbędne dzisiaj do prawidłowego funkcjonowania ogólnego prawa podatkowego.

Przygotowany projekt NOP zawiera ponad 20 takich całkowicie nowych regulacji. Nie ma potrzeby ich szczegółowego omawiania - są one przedstawione w uzasadnieniu projektu ${ }^{13}$. Przykładowo jedynie można wskazać na: zasady ogólne prawa podatkowego, wspomniane niewładcze sposoby załatwiania spraw podatkowych, procedurę konsultacji skutków podatkowych dokonanych transakcji, środki zwalczania przewlekłości postępowania, postępowanie uproszczone w sprawie reprezentatywnej i dotyczące bagatelnych kwot podatku, możliwość rezygnacji z odwołania od decyzji na rzecz skargi do sądu administracyjnego, zakaz orzekania na niekorzyść podatnika przez organ pierwszej instancji czy też

9 M. Popławski, Tax Code Models [w:] Tax Codes Concepts in the Countries of Central and Eastern Europe, ed. L. Etel, M. Popławski, Białystok 2016, s. 15-28.

10 Jest to nowy dział IIB ordynacji dodany powołaną ustawą z 16 października $2019 \mathrm{r}$. o rozstrzyganiu sporów dotyczących podwójnego opodatkowania oraz zawieraniu uprzednich porozumień cenowych.

11 H. Filipczyk, Programy poprawnego rozliczania opartego na wspótpracy (cooperative compliance) jako instrument zwalczania unikania opodatkowania, „Kwartalnik Prawa Podatkowego" 2014, nr 1, s. 9-14.

12 Zob. wyniki badań empirycznych zaprezentowane w: P. Pietrasz, J. Siemieniako, E. Wróblewska, Czynniki zmniejszajace role władczych form działania administracji skarbowej w realizacji zobowiązań podatkowych, Warszawa-Białystok 2013, s. 95 i n.

13 Uzasadnienie projektu ustawy - Ordynacja podatkowa, druk sejmowy nr 3517/VIII kad., s. 11-18. 
urzędowe informacje ogólne o istotnych zmianach przepisów prawa podatkowego. Wprowadzenie tych nowości w drodze kolejnych nowelizacji obowiązującej ordynacji nie jest możliwe bez naruszenia zasad przyzwoitej legislacji. Są to bowiem zmiany wymagające generalnej przebudowy obowiązujących przepisów w kilku działach ordynacji podatkowej.

Pozwala to twierdzić, że obowiązująca ordynacja blokuje możliwość wprowadzania potrzebnych unormowań. W tej sytuacji jedynie uchwalenie nowego aktu może ten problem rozwiązać. Nie będzie wówczas konieczności wprowadzenia tych unormowań „na siłę” do starego układu ustawy, w drodze jej ciągłych nowelizacji, z naruszeniem zasad przyzwoitej legislacji. Alternatywą - złą - jest rozłożenie w czasie wprowadzania nowych instytucji do „starej” ordynacji. Przykładem użycia takiej wątpliwej techniki legislacyjnej może być wprowadzenie do tej ustawy w 2015 r. jednej z całego katalogu zasad prawa podatkowego, a mianowicie zasady rozstrzygania wątpliwości prawnych na korzyść podatnika (art. 2a) ${ }^{14}$. Niewątpliwie zasady ogólne powinny się znaleźć w części ogólnej ordynacji, co jest powszechnie akceptowane ${ }^{15}$. W chwili obecnej można już mówić o ukształtowaniu się w orzecznictwie i doktrynie kilku podstawowych dyrektyw postępowania, które określane są zasadami ogólnego prawa podatkowego. Nie wszystkie jednak są wyartykułowane w obowiązującej ordynacji. Nie ma np. zasady ugodowego załatwiania spraw, zasady wyważenia interesu podatnika i interesu publicznego, zasady rozstrzygania wątpliwości faktycznych na korzyść podatnika czy też zasady współdziałania podatnika z organami podatkowymi. Powinny one być w komplecie wprowadzone do ordynacji. Nie należy jednak - jak zrobiono to w przypadku wskazanego art. 2a - wprowadzić tylko jednej z nich, z pominięciem innych, równie ważnych zasad. One także powinny znaleźć się w ordynacji w odpowiednim miejscu (cześć ogólna) i formie (uporządkowany katalog). Jak to zrobić? Na pewno nie poprzez kolejne nowelizacje tej ustawy, w wyniku których niektóre z zasad zostałyby do niej dopisane w przypadkowych miejscach. Wprowadzenie nowych zasad ogólnych prawa podatkowego jest możliwe tylko w części ogólnej nowej ordynacji. Podobnie rzecz ma się z innymi instytucjami, które są potrzebne już teraz i nie powinny być latami wprowadzane do ordynacji w wyniku kolejnych nowelizacji tego aktu.

14 Ustawa z 5 sierpnia 2015 r. o zmianie ustawy - Ordynacja podatkowa oraz niektórych innych ustaw nowelizacja procedury podatkowej, Dz.U. poz. 1197.

15 A. Gomułowicz, Zasady podatkowe [w:] System prawa finansowego, t. III, Prawo daninowe, red. L. Etel, Warszawa 2010, s. 99-130; B. Brzeziński, Zasady ogólne prawa podatkowego a założenia nowej ordynacji podatkowej, „Przegląd Orzecznictwa Podatkowego" 2016, nr 3, s. 211-219; B. Brzeziński, W. Nykiel, Zasady ogólne prawa podatkowego, „Przegląd Podatkowy” 2002, nr 3, s. 9-11. 


\section{Wiele regulacji źle funkcjonujących w obowiązującej ustawie można zmodyfikować jedynie w nowej ordynacji podatkowej}

Kolejną przyczyną uzasadniającą potrzebę szybkiego uchwalenia NOP jest to, że niektóre z rozwiązań wprowadzonych w życie ponad 20 lat temu uległy dezaktualizacji i muszą ulec generalnej przebudowie ${ }^{16}$. Nie jest to możliwe w drodze nowelizacji obowiązującej ustawy. Nie pozwalają na to zasady techniki legislacyjnej, i tak już wielokrotnie łamane przy kolejnych nowelizacjach ${ }^{17}$.

Przygotowany przez KKOPP projekt NOP zawiera kilkanaście instytucji całkowicie zmodyfikowanych w stosunku do ich obowiązującego kształtu. Najważniejsze z nich dotyczą: podstawowych pojęć i definicji, solidarności w prawie podatkowym, zastosowania środków komunikacji elektronicznej, decyzji cząstkowych, przedawnienia wymiaru i poboru zobowiązań podatkowych, nadpłaty, deklaracji podatkowych, kary porządkowej. Także w tym przypadku nie ma miejsca na chociażby ich ogólnikowe przedstawienie. Są one szeroko omówione w uzasadnieniu projektu i piśmiennictwie ${ }^{18}$.

Jako przykład unormowań, które funkcjonują źle i muszą być szybko zmienione, powszechnie wskazuje się przepisy regulujące przedawnienie zobowiązań podatkowych. Postulat ten jest jak najbardziej zasadny. Obowiązujący model instytucji przedawnienia ma dwie zasadnicze wady. Pierwsza z nich to istnienie dwóch różnych terminów przedawnienia w zależności od tego, w jaki sposób powstaje zobowiązanie podatkowe. W przypadku podatków, w których zobowiązanie powstaje przez doręczenie decyzji, organ podatkowy jest uprawniony do dokonania ich wymiaru przez okres 3 lub 5 lat, a następnie po powstaniu zobowiązania ma 5 lat na pobór podatku. Natomiast w przypadku podatków powstających z mocy prawa obowiązuje jednolity termin na wymiar i pobór podatku wynoszący 5 lat. Nie powinno tak być, że ten sam podatek ulega przedawnieniu $\mathrm{w}$ różnych okresach. Termin przedawnienia nie powinien być uzależniony od sposobu powstawania zobowiązania podatkowego. Kolejnym mankamentem jest długość terminu przedawnienia zobowiązań podatkowych, o którym mowa $\mathrm{w}$ art. 70 o.p. Zgodnie z tym przepisem zobowiązanie podatkowe przedawnia się $\mathrm{z}$ upływem 5 lat, licząc od końca roku kalendarzowego, w którym upłynął termin płatności podatku. Wskazany termin 5-letni, w następstwie licznych przesłanek zawieszenia jego biegu oraz możliwości jego przerwania, jest wydłużany, w wyni-

16 Na potrzebę dostosowania przepisów ordynacji do obecnych oczekiwań wskazuje m.in. H. Dzwonkowski, Ocena skutków regulacji zawartych w rządowym projekcie ustawy - Ordynacja podatkowa (druk nr 3517), Biuro Analiz Sejmowych Kancelarii Sejmu, 2 lipca 2019 r., s. 1, niepubl.

17 Rozporządzenie Prezesa Rady Ministrów z 20 czerwca 2002 r. w sprawie „Zasad techniki prawodawczej”, t.j. Dz.U. 2016, poz. 283.

18 L. Etel i in., Nowa ordynacja podatkowa. Z prac Komisji Kodyfikacyjnej Ogólnego Prawa Podatkowego, Białystok 2017, s. 35 i n. 
ku czego zobowiązanie podatkowe może być egzekwowane nawet po kilkunastu latach. Wyeliminowanie wyżej wskazanych wad obowiązujących przepisów nie jest możliwe w drodze nowelizacji ordynacji. Przepisy regulujące przedawnienie muszą być napisane na nowo. Nowa konstrukcja prawna instytucji przedawnienia została zaproponowana w projekcie przygotowanym przez KKOPP. Opiera się ona na założeniu, że zasady przedawnienia zobowiązań podatkowych (zarówno powstających z mocy prawa, jak i po doręczeniu decyzji) powinny być jednolite. W związku z tym proponuje się wprowadzenie terminu przedawnienia wymiaru i terminu przedawnienia poboru podatku. Okres przedawnienia wymiaru wynosi 3 lata lub 5 lat liczone od dnia upływu terminu płatności lub powstania obowiązku podatkowego. W tym czasie organ podatkowy musiałby doręczyć decyzję ustalającą lub określającą wysokość zobowiązania podatkowego. Po upływie okresu przedawnienia wymiaru następowałby 5-letni okres przedawnienia poboru. W tym czasie organy podatkowe mogłyby egzekwować podatki wynikające z deklaracji lub decyzji. Możliwości przerywania i zawieszania biegu terminu przedawnienia zostały w projekcie mocno ograniczone. Wszystkie wyżej wskazane zmiany w konstrukcji przedawnienia uzasadniają twierdzenie, że jest to $\mathrm{w}$ istocie nowa instytucja ukryta pod starą nazwą. W żadnym razie nie można naprawić obowiązujących przepisów regulujących przedawnienie przez kosmetyczne poprawki. Wyeliminowanie istotnych wad zasad przedawnienia zobowiązań podatkowych jest możliwe jedynie w ramach NOP.

Podobnie rzecz ma się z kolejną fundamentalną instytucją ogólnego prawa podatkowego, jaką jest nadpłata. Obowiązujące regulacje są nadmiernie skomplikowane, a przez to prowadzą do powstawania licznych problemów interpretacyjnych. Nie można ich udoskonalić nawet w drodze gruntownej nowelizacji. W projektowanych przepisach NOP zaproponowano rozwiązania eliminujące problemy związane $\mathrm{z}$ funkcjonowaniem tej instytucji. Wprowadzono regułę, zgodnie z którą niewątpliwie nadpłacone podatki będą zaliczane lub zwracane niezwłocznie bez prowadzenia postępowań i wydawania decyzji. Rozszerzono możliwość wydawania tzw. decyzji cząstkowych, stwierdzających nadpłatę w granicach zakreślonych wnioskiem podatnika. Ujednolicono też terminy zwrotu i oprocentowania nadpłaty oraz jej zaliczania na poczet zaległości podatkowych. Uzależniono zwrot nadpłaty od przesłanki bezpodstawnego wzbogacenia. Przyjęcie tych propozycji przepisów jest potrzebne z uwagi na niekończące się spory podatników z organami podatkowymi, których przedmiotem jest nadpłacony podatek $^{19}$. Po raz kolejny należy zauważyć, że konieczne w tym celu jest uchwalenie NOP.

19 Pojęcie nadpłaty było przedmiotem ponad 10 tys. wyroków sądów administracyjnych - zob. komentarz do art. 72 ordynacji podatkowej, LEX [dostęp 30 października 2019 r.]. 


\section{Konieczność szerokiego wykorzystania w ordynacji środków komunikacji elektronicznej}

Kolejnym przykładem czynnika wymuszającego zmiany w ordynacji jest wykorzystywanie środków komunikacji elektronicznej w kontaktach z podatnikiem. W latach 90. ubiegłego wieku nikt nie sądził, że będzie to jeden z najdogodniejszych i najtańszych sposobów doręczania decyzji, wezwań, składania deklaracji czy też udzielania informacji. W chwili obecnej trzeba wprowadzić do ordynacji przepisy legalizujące wykorzystywanie środków komunikacji elektronicznej zarówno przez organy podatkowe, jak i podatników. Tu znowu pojawia się bariera w postaci konieczności przebudowania przepisów, które powstały ponad 20 lat temu. Jak trudne to zadanie, pokazują wprowadzane sukcesywnie do obowiązującej ordynacji przepisy umożliwiające korzystanie z elektronicznych form komunikowania się i gromadzenia danych. W projekcie NOP problematyka ta została potraktowana jako jeden z priorytetów. Przyjęto zasadę, że wszelkiego rodzaju dokumenty mogą być składane i przesyłane drogą elektroniczną, jeśli podatnik o to wnosi lub na to się zgadza. Środki elektroniczne w nowej ordynacji są traktowane jako podstawowy sposób komunikowania się organu z podatnikiem oraz innymi instytucjami. W projekcie zaproponowano także wprowadzenie taniego i efektywnego sposobu komunikowania się z podatnikiem i jego reprezentantem. Nie może być tak, że doręczenie decyzji podatkowej to dla organu podatkowego kosztowna procedura, nie zawsze skutecznie zakończona. Zgodnie z projektem NOP pisma za pomocą środków komunikacji elektronicznej można doręczać nie tylko profesjonalnym pełnomocnikom i podmiotom publicznym, ale także przedsiębiorcom (z wyjątkiem mikroprzedsiębiorców) oraz użytkownikom systemów teleinformatycznych. Dodatkowo proponuje się, aby dane wskazane w zgłoszeniu ewidencyjnym i przechowywane w Centralnym Rejestrze Podatników Krajowej Ewidencji Podatników stanowiły podstawę do ustalenia adresu miejsca zamieszkania oraz adresu siedziby dla celów doręczania pism. Możliwość skutecznego doręczenia na adres wskazany w tym rejestrze zwiększy skuteczność doręczeń i zmniejszy koszty z tym związane. Podatnikom, których adresu tam nie będzie, pisma będą doręczane na ogólnych zasadach. Potrzeba upowszechnienia stosowania środków komunikacji elektronicznej, nie tylko na gruncie ordynacji podatkowej, obecnie nie podlega dyskusji. Realizacja tego postulatu wymaga jednak uchwalenia nowej ordynacji ${ }^{20}$.

20 L. Etel i in., Nowa ordynacja, op. cit., s. 129 i n. 


\section{Obowiązująca ordynacja podatkowa z 1997 r. utraciła racjonalną systematykę wewnętrzną}

Ciągłe nowelizacje w większości przypadków miały na celu dostosowanie ordynacji do ujawniających się wciąż nowych potrzeb i problemów związanych ze stosowaniem jej przepisów. Poprawiana przez 20 lat ordynacja zatraciła swoją pierwotną strukturę, która także nie była wolna od wad ${ }^{21}$. W obowiązującej ordynacji nie ma już miejsca na wprowadzanie nowych regulacji, co powoduje, że są one zamieszczane w przypadkowych działach i rozdziałach. W efekcie zakłóca to proces prawidłowej wykładni tych przepisów.

Jako przykład można wskazać wspomnianą już zasadę rozstrzygania wątpliwości na korzyść podatnika, stanowiącą treść art. 2a działu I - Przepisy ogól$n e, \mathrm{w}$ sytuacji gdy równie ważna zasada legalizmu jest zamieszczona $\mathrm{w}$ art. 120 w dziale IV - Postępowanie podatkowe. Nikogo nie trzeba przekonywać, że zasady ogólne prawa podatkowego muszą być w jednym miejscu, w pierwszej części ordynacji podatkowej. Jednak „stary” układ ordynacji na to nie pozwala, przez co nolens volens tworzy się tego typu prowizoryczne regulacje.

Nie przynosi dobrych rezultatów zwłaszcza wprowadzanie obszernych unormowań do obowiązującej ustawy. Zapewne najlepiej obrazuje to zawartość całego art. 119 obowiązującej ustawy, gdzie uregulowane są: zasady waloryzacji zastawu skarbowego (art. 119); klauzula przeciwko unikaniu opodatkowania (art. 119a-119zfn) i przeciwdziałanie wykorzystywania sektora finansowego do wyłudzeń skarbowych (art. 119zg-119zzk). Razem jest to 80 podstawowych jednostek redakcyjnych ustawy w rozumieniu $\$ 54$ „Zasad techniki prawodawczej”, „ukrytych” pod jednym numerem z literkami. W jaki sposób powstają tego typu „potworki” legislacyjne? Odpowiedź jest bardzo prosta. Jest to wynik braku miejsca w ustawie na nowe unormowania. W przypadku nieuchwalenia nowej ustawy artykułów z literkami będzie coraz więcej, przez co i tak trudny w odbiorze akt stanie się jeszcze bardziej nieczytelny.

Są także inne, zaskakujące, następstwa wprowadzania do ordynacji nowych rozwiązań. Jednym $z$ nich jest to, że obowiązująca ustawa ma trzy słowniczki ustawowe. Pierwszy z nich jest w art. 3 (dział I - Przepisy ogólne), drugi - w art. 86a (dział III - Zobowiązania podatkowe, rozdział 11a - Informacje o schematach podatkowych) i trzeci - w art. 119zg (dział IIIB - Przeciwdziałanie wykorzystywaniu sektora finansowego do wyłudzeń skarbowych, rozdział 1- Przepisy ogólne). Nie najlepiej to świadczy o systematyce aktu prawnego o charakterze kodeksowym. Potwierdza to już wcześniej sygnalizowaną potrzebę uregulowania w odrębnych ustawach (lub ustawie) instytucji uchwalanych w celu zwalczania zjawiska ucieczki od podatku. I tak np. układ działu IIIB - Przeciwdziałanie wy-

${ }^{21}$ Zob. C. Kosikowski, H. Dzwonkowski, A. Huchla, Ustawa - Ordynacja podatkowa. Komentarz, Warszawa 2003, s. 27. 
korzystywaniu sektora finansowego do wyłudzeń skarbowych, wyraźnie wskazuje, że są tu wyczerpująco uregulowane wszystkie sprawy związane $\mathrm{z}$ funkcjonowaniem systemu teleinformatycznego izby rozliczeniowej. Na początku są przepisy ogólne ze wspomnianym słowniczkiem pojęć występujących w tym dziale, następnie przepisy materialne (analiza ryzyka), proceduralne (blokada rachunku podmiotu kwalifikowanego i postępowanie kontrolne) i na końcu przepisy karne. Spełnione są więc wszystkie wymogi uregulowania tej kategorii spraw w odrębnej ustawie ( $\$ 2$ i $\$ 20$ Zasad techniki prawodawczej). Regulacja ta nie powinna znaleźć się w ordynacji podatkowej. Na pewno byłoby to z korzyścią dla obowiązującej ordynacji, a zwłaszcza jej systematyki i stabilności.

\section{W projekcie nowej ordynacji zachowano dobrze funkcjonujące przepisy obowiązującej ustawy}

Nie zachodzi obawa, że w następstwie uchwalenia nowego aktu podatnicy i pracownicy organów podatkowych będą musieli „uczyć się" na nowo ordynacji. Podstawowe reguły obecnej ustawy zostały zachowane w projekcie. Nie przepadnie też 20-letni dorobek sądów i doktryny odnoszący się do obowiązujących przepisów. Tworząc nowe przepisy, uwzględniono natomiast wszelkie problemy sygnalizowane przez judykaturę i naukę. W projekcie zaproponowano rozwiązanie ciągnących się latami sporów interpretacyjnych, wymagających interwencji ustawodawcy (np. bezpodstawne wzbogacenie w wyniku zwrotu nadpłaty albo bieg terminu przedawnienia przy zaległościach zabezpieczonych hipoteką). Projektując nową ustawę, KKOPP wykorzystała te rozwiązania prawne, które sprawdziły się w praktyce. Stąd też w projekcie jest dużo przepisów przeniesionych $z$ obowiązującej ordynacji. Nie jest to wada projektu, ale jego zaleta ${ }^{22}$. Nie ma sensu rezygnować z przepisów, które przez 20 lat dobrze funkcjonowały. KKOPP stała na stanowisku, zgodnie z którym ogólne prawo podatkowe powinno być tworzone w drodze ewolucji, a nie radykalnych reform.

\section{Tryb przygotowania projektu nowej ordynacji}

Za uchwaleniem nowej ustawy przemawia także tryb przygotowania jej projektu. Projekt opracowała KKOPP, złożona, jak wskazano na wstępie, z przedstawicieli nie tylko Ministerstwa Finansów, ale także nauki, sądów i doradców podatko-

22 L. Etel, Niepoważne uwagi poważnych instytucji - polemika z uwagami krytycznymi do projektu nowej ordynacji podatkowej [w:] Wspótczesne problemy prawa podatkowego. Ksiegga jubileuszowa dedykowana Profesorowi Bogumiłowi Brzezińskiemu, t. 1, Teoria i praktyka, Warszawa 2019, s. 119-121. 
wych. Najpierw przygotowane zostały kierunkowe założenia nowego aktu (styczeń 2015 r.), następnie zostały one poddane konsultacjom resortowym i publicznym, trwającym od lutego do września 2015 r. Po zakończeniu konsultacji kierunkowe założenia zostały zaakceptowane przez Radę Ministrów (październik 2015 r.). Na tej podstawie KKOPP przygotowała projekt ustawy i przekazała go Ministrowi Finansów (październik 2017 r.). Projekt nowej ordynacji został skierowany do tzw. konsultacji wewnątrzresortowych (zakończonych w czerwcu 2018 r.). Po ich przeprowadzeniu rozpoczęły się konsultacje międzyresortowe i publiczne (zakończone w styczniu 2019 r.). Komisja współpracowała z Ministerstwem Finansów przy analizie uwag zgłoszonych w trakcie konsultacji. Projekt został w czerwcu 2019 r. skierowany do Sejmu.

Jak widać, nie był to projekt przygotowywany w pośpiechu - prace nad nim trwały prawie 5 lat. $Z$ tego dużo czasu poświęcono na konsultacje. Objęte nimi były zarówno kierunkowe założenia nowej ustawy (8 miesięcy), jak i jej projekt (15 miesięcy). Istotna część uwag zgłoszonych podczas konsultacji została uwzględniona w kolejnych wersjach projektu. Nie wszystkie jednak - z różnych powodów - mogły być rozpatrzone pozytywnie ${ }^{23}$.

Wbrew pozorom krytyka projektu ordynacji podatkowej nie jest argumentem przemawiającym za jego odrzuceniem. Jest to zjawisko, które towarzyszy w zasadzie wszystkim ważnym aktom prawnym, w tym również ordynacjom podatkowym. Sformułowano wiele zarzutów dotyczących ordynacji podatkowej uchwalonej w roku $1934^{24}$. Na niekonstytucyjność większości przepisów części ogólnej wskazywano w odniesieniu do obowiązującej ordynacji ${ }^{25}$. Jak widać, te bardzo poważne zarzuty dotyczące kształtu tych ordynacji nie przeszkodziły w ich uchwaleniu. Z perspektywy czasu należy pozytywnie ocenić obie te ustawy i wskazać, że ich uchwalenie porządkowało część ogólną prawa podatkowego. Jedynie wieloletnie stosowanie w praktyce przepisów ordynacji daje podstawy do ich oceny. Moim zdaniem zarówno ordynacja z 1934 r., jak i ta z 1997 r., to ustawy potrzebne w momencie ich uchwalania, które usprawniły funkcjonowanie systemu podatkowego. Od aktów tego typu nie można jednak oczekiwać, że postanowienia z nich wynikające będą miały charakter ponadczasowy. Nawet najlepsza ordynacja ulega stopniowemu zużyciu (dezaktualizacji) i powinna być zastąpiona nową.

Przedstawiony tryb pracy nad projektem uzasadnia tezę, że projekt ten został przygotowany z zachowaniem zasad poprawnej legislacji. To, jeśli nie gwarantuje, to mocno uprawdopodabnia, że uchwalona na podstawie tego projektu ustawa

23. Ibidem, s. 118.

24 Zob. D. Janicka, O znaczeniu ordynacji podatkowej z 1934 r. Uwagi w stulecie rozpoczęcia unifikacji prawa podatkowego w Polsce [w:] Współczesne problemy prawa podatkowego. Księga jubileuszowa dedykowana Profesorowi Bogumiłowi Brzezińskiemu, t. 1, Teoria i praktyka, Warszawa 2019, s. 202.

25 Zob. C. Kosikowski, Konstytucyjność Ordynacji podatkowej, „Państwo i Prawo” 1998, z. 2, s. 3-11. 
będzie dobrze funkcjonowała. Za projektem KKOPP przemawia również to, że przygotowanie innego na pewno zajmie kilka lat, przez co zmniejszy się szansa na jego uchwalenie jeszcze w tej kadencji parlamentu.

\section{Wnioski}

Zasadne jest podjęcie prac zmierzających do uchwalenia nowej ordynacji podatkowej. W obowiązującej ordynacji nie ma wielu instytucji charakterystycznych dla współczesnych aktów tego typu. Należy także generalnie przebudować wiele regulacji, które uległy dezaktualizacji z uwagi na dynamiczny rozwój prawa podatkowego. Jednakże wprowadzanie nowych regulacji do obowiązującego aktu jest, z uwagi na wymogi techniki legislacyjnej, bardzo trudne, a czasami niemożliwe. „Stary” kształt prawny ordynacji blokuje prawidłowe wprowadzenie potrzebnych dzisiaj regulacji. Jednocześnie - z różnych powodów - ordynacja jest często nowelizowana. Ciągłe zmiany ordynacji doprowadziły do tego, że systematyka i układ jej przepisów są dalekie od doskonałości. Utrudnia to stosowanie jej przepisów w praktyce i powoduje powstawanie licznych sporów w relacjach podatnik - organ podatkowy. Analiza dokonanych w ostatnich latach licznych nowelizacji jednoznacznie wskazuje, że nie jest to już dobry sposób jej „poprawiania”. W tej sytuacji trzeba uchwalić nową ustawę na bazie przygotowanego przez KKOPP projektu. Nie jest to projekt wolny od wad, co wykazano w trakcie szeroko przeprowadzonych konsultacji ${ }^{26}$, ale można je łatwo wyeliminować w procesie legislacyjnym. Alternatywą są dalsze nowelizacje, w wyniku których w ordynacji pojawi się art. $119 \mathrm{zzzz...}$

\section{Bibliografia}

Adamiak B., Borkowski J., Mastalski R., Zubrzycki J., Ordynacja podatkowa. Komentarz 2014, Wrocław 2014.

Brzeziński B., Ordynacja podatkowa w świetle kryteriów oceny jakości aktów normatywnych [w:] Ordynacja podatkowa. Wokół nowelizacji, red. R. Dowgier, Białystok 2009.

Brzeziński B., Zasady ogólne prawa podatkowego a założenia nowej ordynacji podatkowej, „Przegląd Orzecznictwa Podatkowego” 2016, nr 3.

Brzeziński B., Nykiel W., Zasady ogólne prawa podatkowego, „Przegląd Podatkowy” 2002, nr 3.

Dowgier R., O konieczności uwzględnienia w ordynacji podatkowej specyfiki podatków samorzadowych [w:] Ordynacja podatkowa. Stan obecny i kierunki zmian, red. R. Dowgier, Warszawa 2015.

26 Zob. uwagi H. Dzwonkowskiego, Ocena skutków regulacji zawartych w rządowym projekcie, op. cit. 
Dzwonkowski H., Ocena skutków regulacji zawartych w rządowym projekcie ustawy - Ordynacja podatkowa (druk nr 3517), Biuro Analiz Sejmowych Kancelarii Sejmu, 2 lipca 2019 r., niepubl.

Etel L., Niepoważne uwagi poważnych instytucji - polemika z uwagami krytycznymi do projektu nowej ordynacji podatkowej [w:] Wspótczesne problemy prawa podatkowego. Księga jubileuszowa dedykowana Profesorowi Bogumiłowi Brzezińskiemu, t. 1, Teoria i praktyka, Warszawa 2019.

Etel L. i in., Nowa ordynacja podatkowa. Z prac Komisji Kodyfikacyjnej Ogólnego Prawa Podatkowego, Białystok 2017.

Etel L. i in., Ordynacja podatkowa. Kierunkowe założenia nowej regulacji, Białystok 2015.

Filipczyk H., Programy poprawnego rozliczania opartego na współpracy (cooperative compliance) jako instrument zwalczania unikania opodatkowania, „Kwartalnik Prawa Podatkowego" 2014, nr 1.

Gomułowicz A., Zasady podatkowe [w:] System prawa finansowego, t. III, Prawo daninowe, red. L. Etel, Warszawa 2010.

Janicka D., O znaczeniu ordynacji podatkowej z 1934 r. Uwagi w stulecie rozpoczęcia unifikacji prawa podatkowego w Polsce [w:] Wspótczesne problemy prawa podatkowego. Księga jubileuszowa dedykowana Profesorowi Bogumiłowi Brzezińskiemu, t. 1, Teoria i praktyka, Warszawa 2019.

Konferencja „Zmiany w Ordynacji podatkowej. Poprawa jakości i uproszczenia”, Warszawa, 8 stycznia 2013 r., red. G. Gołębiowski, H. Dzwonkowski, Warszawa 2013.

Kosikowski C., Konstytucyjność Ordynacji podatkowej, „Państwo i Prawo” 1998, z. 2.

Kosikowski C., Ogólny kodeks daninowy zamiast ordynacji podatkowej, „Przegląd Podatkowy" 2014, nr 9.

Kosikowski C., Dzwonkowski H., Huchla A., Ustawa - Ordynacja podatkowa. Komentarz, Warszawa 2003.

Pietrasz P., Siemieniako J., Wróblewska E., Czynniki zmniejszające rolę władczych form działania administracji skarbowej $w$ realizacji zobowiazań podatkowych, WarszawaBiałystok 2013.

Popławski M., Tax Code Models [w:] Tax Codes Concepts in the Countries of Central and Eastern Europe, ed. L. Etel, M. Popławski, Białystok 2016. 